\title{
GAMBARAN PERTOLONGAN PERTAMA DALAM KELUARGA PADA PENANGANAN BALITA DIARE DI POLI MTBS UPTD PUSKESMAS SE-KOTA BLITAR
}

\author{
Triana Setijaningsih ${ }^{1 *}$, Rahmawati, Hawari ${ }^{2}$ \\ 1, Jurusan Keperawatan Poltekkes Kemenkes Malang \\ 2, Mahasiswa keperawatan Poltekkes Kemenkes Malang \\ *E-mail: trianasetijaningsih@gmail.com
}

\begin{abstract}
Abstrak
Diare adalah buang air besar berbentuk cair lebih dari 3 kali sehari dan jumlahnya lebih banyak. Menurut World Health Organization (WHO) diare menempati urutan keempat penyebab kematian anak di dunia, yaitu sebesar 9\% (WHO, 2015). Dari data kasus balita diare di Kota Blitar pada tahun 2016 dan 2017 menunjukkan adanya peningkatan sebanyak 52 kasus. Tujuan penelitian untuk menggambarkan pertolongan pertama dalam keluarga pada penanganan balita diare. Desain penelitian menggunakan rancangan deskriptif dengan populasi keluarga yang pernah memeriksakan balita diare di Poli MTBS UPTD Puskesmas se-Kota Blitar, sampel sebanyak 32 keluarga dengan teknik Accidental Sampling dan pengumpulan data dengan bantuan kuesioner.. Hasilnya menunjukkan bahwa $62.5 \%$ dengan kategori baik, $28.1 \%$ dengan kategori cukup dan 9.4\% dengan kategori kurang. Pertolongan pertama baik karena seluruh keluarga sudah memberikan cairan lebih banyak dari biasanya. Pertolongan pertama cukup karena sebagian kecil keluarga tidak memberikan cairan meskipun diare sudah berhenti. Pertolongan pertama kurang karena sebagian besar keluarga memberikan obat anti diare saat balita mengalami diare. Rekomendasi penelitian diharapkan dapat digunakan sebagai bahan penyusunan kegiatan dalam hal pertolongan pertama diare di UPTD Puskesmas se-Kota Blitar.
\end{abstract}

Kata kunci : Pertolongan Pertama, Keluarga, Penanganan Balita Diare.

\begin{abstract}
Description of First Aidin Family in The Management of Diarhea in Poly of Integrated Management of Children With Illness in the Public Health Center of Blitar City. Diare is a condition of liquid defecation more than three times a day and in large amounts. According to the World Health Organization (WHO), diarrhea placed the fourth rank of the death cause for infants in the world, cases for infants in blitar town in 2016 and 2017, showed an increase for 52 cases. The aim of this study is for describing the first aid in the family for treating kids with diarrhea. The design of the study used a descriptive plan with the family population who have checked their kids with diarrhea in poli MTBS UPTD Puskesmas in Blitar Town, the sample is 32 families by using the accidental sampling technique and the data collection with the help of a questionnaire. The result showed that 62,5\% was categorized good, 28,1\% enough, and 9,4\% is less. The first aid is good because all family members were given liquid more than usual. The first aid is enough because a few families didn't give enough liquid although most families gave anti-diarrhea medicine when kids got diarrhea. The recommendation of the study is aimed to be able to be used as material to arrange an activity in the first aid for diarrhea in UPTD Puskesmas.
\end{abstract}

Keywords: first aid, family, infant diarrhea 


\section{Pendahuluan}

Anak merupakan individu yang berada dalam satu rentang perubahan pertumbuhan dan perkembangan yang dimulai dari bayi hingga remaja (Hidayat, 2008:6). Di Kota Blitar jumlah balita pada tahun 2016 adalah 8730, di Kecamatan Sananwetan 4113 balita, di Kecamatan Kepanjenkidul 2463 dan di Kecamatan Sukorejo 2154 balita. Anak usia balita rentan terkena penyakit karena anak mulai aktif bermain dan daya tahan tubuhnya masih lemah, dapat menyebabkan anak mudah tertular penyakit atau gangguan kesehatan lain. Salah satu kebiasaan anak yaitu memasukkan jari tangan mereka ke dalam mulut, sehingga anak mudah terinfeksi virus atau bakteri yang dapat menyebabkan penyakit seperti diare yang penularannya melalui fekaloral. Oleh karena itu, kesehatan anak harus mendapat perhatian dari keluarga agar anak tumbuh dan berkembang dengan optimal.

Keluarga adalah kumpulan 2 orang atau lebih yang hidup bersama dengan keterikatan aturan dan emosional individu mempunyai peran masing-masing yang merupakan bagian dari keluarga (Friedman dalam Suprajitno, 2004:1). Menurut Freeman dalam Setiadi (2008:13), salah satu tugas keluarga dalam bidang kesehatan yaitu mengambil keputusan untuk melakukan tindakan yang tepat bagi keluarga. Tugas ini merupakan upaya keluarga yang utama untuk mencari pertolongan yang tepat sesuai dengan keadaan keluarga agar masalah kesehatan dapat dikurangi atau bahkan teratasi. Salah satu penyakit yang membutuhkan pertolongan yang cepat dan tepat oleh keluarga yaitu diare.

Menurut Hidayat (2008:12) diare merupakan suatu keadaan pengeluaran tinja yang tidak normal atau tidak seperti biasanya, ditandai dengan peningkatan volume, keenceran, serta frekuensi lebih dari 3 kali sehari dan pada neonatus lebih dari 4 kali sehari dengan atau tanpa lendir darah. Penyebab utama penyakit diare adalah infeksi bakteri atau virus. Apabila diare tidak segera ditangani, tubuh anak akan kehilangan banyak cairan (dehidrasi) yang dapat menyebabkan kematian. Menurut World Health Organization (WHO) diare menempati urutan keempat penyebab kematian anak di dunia, yaitu sebesar 9\% (WHO, 2015). Oleh karena itu, peran keluarga dalam memberikan pertolongan pertama balita diare sangat penting, yaitu dengan memberikan cairan lebih banyak dari biasanya seperti cairan rumah tangga atau cairan rehidrasi oral. Memberikan nutrisi yang cukup baik diit normal maupun diit lunak dan segera membawa anak ke fasilitas kesehatan apabila diare lebih sering, muntah berulang atau berak disertai darah, (Bahren, 2014:35). Namun, bahaya dehidrasi ini tidak dikhawatirkan oleh sebagian masyarakat karena adanya stigma bahwa diare 
sering dikatakan tidak apa-apa, karena diare berarti "ngentengin badan" dan dengan demikian balita akan bertambah pintar (Noorkasiani, 2009:48).

Secara nasional angka kematian (CFR) pada KLB diare pada tahun 2014 tidak mencapai target program, yaitu sebesar $1,14 \%$ sedangkan target CFR pada KLB diare diharapkan <1 (Kemenkes RI, 2015). Di Jawa Timur, cakupan penemuan kasus diare per bulan mulai tahun 2009 sampai tahun 2014 cenderung meningkat setiap tahunnya, dari 100.000 kasus menjadi 600.000 kasus (Dinkes Jatim, 2016). Di Kota Blitar, jumlah kasus balita diare pada tahun 2016 sebesar 588 kasus yang tersebar di tiga kecamatan, yaitu Kecamatan Kepanjenkidul 221 kasus, Kecamatan Sukorejo 170 kasus dan Kecamatan Sananwetan 197 kasus. Dari kasus diare tersebut, terdapat 88 kasus mengalami dehidrasi di Kecamatan Sananwetan dengan persentase $26 \%$ mengalami dehidrasi ringan/sedang dan $18 \%$ mengalami dehidrasi berat. Sedangkan di Kecamatan Kepanjenkidul terdapat $22 \%$ balita mengalami dehidrasi berat. Pada tahun 2017 kasus balita diare meningkat menjadi 640 kasus, di Kecamatan Kepanjenkidul 203 kasus, Kecamatan Sukorejo 228 dan Kecamatan Sananwetan 209 kasus.

Hasil studi pendahuluan yang dilakukan dengan pemeriksaan dan wawancara pada tanggal 1-3 November 2017 di UPTD Puskesmas Kecamatan Sukorejo Kota Blitar dengan 10 keluarga yang mempunyai anak usia balita, didapatkan 1 keluarga memberikan oralit, 2 keluarga memberikan larutan gula garam, dan 7 keluarga tidak memberikan apaapa saat anak diare. Dari 10 anak tersebut, 7 orang anak mengalami dehidrasi ringan/sedang dengan keadaan mata cekung, rewel dan cubitan perut kembalinya lambat, dan 3 orang anak tidak mengalami dehidrasi. Serta terdapat 2 keluarga yang percaya bahwa diare dapat "ngentengin badan" dan membuat anak pintar.

Berdasarkan uraian diatas, penulis tertarik untuk meneliti tentang "Gambaran Pertolongan Pertama dalam Keluarga pada Penanganan Balita Diare di Poli MTBS UPTD Puskesmas se-Kota Blitar”.

\section{Metode}

Rancangan penelitian yang digunakan pada penelitian ini rancangan penelitian deskriptif. Penelitian ini bertujuan untuk mengetahui gambaran pertolongan pertama pada keluarga dalam penanganan balita diare di Poli MTBS UPTD Puskesmas se-Kota Blitar.

Populasi yang digunakan adalah keluarga yang pernah memeriksakan balita diare di Poli MTBS UPTD Puskesmas se-Kota Blitar. Jumlah keluarga yang memeriksakan 
balita diare pada bulan Januari - Maret 2018 sebanyak 117 balita dengan rata-rata setiap bulannya sebanyak 39 balita. Sebagai Sampelnya salah satu anggota keluarga (ayah/ibu/kerabat) yang memeriksakan balita diare di Poli MTBS UPTD Puskesmas se-Kota Blitar. Waktu pengambilan data selama 18 hari yaitu pada tanggal 17 April - 06 Mei 2018, sebanyak 32 anggota keluarga. Teknik sampling yang digunakan Accidental Sampling.

Instrumen pengumpulan data menggunakan kuesioner yang dibuat sendiri oleh peneliti berdasarkan kajian teori yang ada. Instrument menggunakan kuesioner tertutup, responden hanya memilih jawaban yang telah disediakan. Poin-poin yang ditanyakan pada kuesioner meliputi: Karakteristik responden, Pertolongan pertama dalam keluarga pada penanganan balita diare, Pertolongan pertama dalam keluarga pada penanganan balita diare berdasarkan parameter.

Kuesioner tersebut sudah diuji cobakan kepada 10 orang dengan karakteristik seperti responden sebanyak 2 kali. Adanya kekurangan diperbaiki sampai responden bisa memahaminya.

Hasil jawaban responden dibagi dengan skor maksimal dan dikalikan 100\%. Perolehan terakhir yang diperoleh berupa persentase menggunakan rumus (Sutomo, 2011:53):

$$
\mathrm{P}=\frac{f f}{N N} \times 100 \%
$$

$$
\begin{aligned}
& \mathrm{P}=\text { Prosentase } \\
& \mathrm{f}=\text { Jumlah jawaban yang benar } \\
& \mathrm{N}=\text { Jumlah soal }
\end{aligned}
$$

Penentuan pertolongan pertama pada keluarga dalam penanganan balita diare dengan cara mengkonversikannya ke dalam kategori sebagai berikut:

Nilai $76-100 \%=$ Baik

Nilai $56-75 \%=$ Cukup

Nilai $\leq 55 \%=$ Kurang

(Sutomo, 2011:54).

\section{Hasil}

Penelitian dilaksanakan di UPTD Puskesmas se-Kota Blitar, yang dibuktikan dengan surat keterangan bahwa yang bersangkutan benar-benar telah melaksanakan penelitian. Hasil penelitian menunjukkan karakteristik respoden sebagian besar $68.8 \%$ (22 keluarga balita) berjenis kelamin laki-laki, sebagian 53.1\% (17 keluarga balita) berusia 12-24 bulan, hampir seluruh 84.4\% (27 keluarga balita) berusia 21-40 tahun, sebagian kecil 34.4\% (11 keluarga balita) berpendidikan SMA, sebagian 59.4\% (12 keluarga balita) bekerja sebagai ibu rumah tangga, hampir seluruh $84.4 \%$ (27 keluarga balita) pernah mendapat informasi tentang pertolongan pertama balita diare, sebagian besar $62.5 \%$ (20 keluarga balita) mendapatkan informasi tentang pertolongan pertama balita diare dari petugas kesehatan, hampir seluruh $81.3 \%$ (26 
keluarga balita) pernah merawat balita diare, sebagian $43.8 \% \quad$ (14 keluarga balita) memberikan cairan lebih banyak dari biasanya saat balita diare, seluruh 100\% (32 keluarga balita) mengetahui pengertian diare, dan sebagian besar $75 \%$ (24 keluarga balita) tidak mempunyai kepercayaan bahwa diare berarti "ngentengin badan" dan membuat anak pintar.

\section{Pertolongan pertama dalam keluarga pada penanganan balita diare}

Dari hasil penelitian didapatkan data tentang pertolongan pertama dalam keluarga pada penanganan balita diare dapat dilihat pada tabel dibawah ini.

Tabel 1 Distribusi frekuensi pertolongan pertama dalam keluarga pada penanganan balita diare

\begin{tabular}{lcc}
\hline $\begin{array}{c}\text { Pertolongan } \\
\text { Pertama }\end{array}$ & Frekuensi & Prosentase \\
\hline Baik & 20 & $62.5 \%$ \\
Cukup & 9 & $28.1 \%$ \\
Kurang & 3 & $9.4 \%$ \\
\hline \multicolumn{1}{c}{ Total } & 32 & 100 \\
\hline
\end{tabular}

Berdasarkan tabel 1 diketahui bahwa sebagian besar anggota keluarga memiliki upaya yang baik dalam melakukan pertolongan pertama balita diare yaitu sebesar $62.5 \%$ (20 keluarga).

\section{Pertolongan pertama dalam keluarga pada penanganan balita diare berdasarkan parameter.}

Tabel 2 Parameter pertolongan pertama dalam keluarga pada penanganan balita diare

\begin{tabular}{|c|c|c|c|}
\hline \multirow[t]{2}{*}{ Parameter } & \multicolumn{3}{|c|}{ Pertolongan Pertama } \\
\hline & Baik & Cukup & Kurang \\
\hline Memberikan & 19 & 9 & 4 \\
\hline Cairan Lebih & $59.4 \%$ & $28.1 \%$ & $12.5 \%$ \\
\hline Banyak dari & & & \\
\hline Biasanya & & & \\
\hline Memberikan & 12 & 12 & 8 \\
\hline Nutrisi yang & $37.5 \%$ & $37.5 \%$ & $25.0 \%$ \\
\hline Cukup & & & \\
\hline Membawa ke & 30 & - & 2 \\
\hline $\begin{array}{l}\text { Fasilitas } \\
\text { Kesehatan }\end{array}$ & $93.8 \%$ & & $6.2 \%$ \\
\hline
\end{tabular}

Berdasarkan tabel 2 diketahui bahwa pertolongan pertama dalam keluarga pada penanganan balita diare di Poli MTBS UPTD Puskesmas se-Kota Blitar didapatkan kategori baik parameter membawa ke fasilitas kesehatan 93.8\% (30 keluarga), kategori cukup parameter memberikan nutrisi yang cukup 37.5\% (12 keluarga) dan kategori kurang parameter memberikan memberikan nutrisi yang cukup 25\% (keluarga).

\section{Pembahasan}

Berdasarkan hasil penelitian gambaran pertolongan pertama dalam keluarga pada penanganan balita diare di Poli MTBS UPTD Puskesmas se-Kota Blitar dengan jumlah responden 32 keluarga didapatkan hasil sebagian besar keluarga 62.5\% (20 keluarga) 
melakukan pertolongan pertama balita diare dengan kategori baik, sebagian kecil keluarga $28.1 \%$ (9 keluarga) melakukan pertolongan pertama balita diare dengan kategori cukup, dan sangat sedikit keluarga 9.4\% (3 keluarga) melakukan pertolongan pertama balita diare dengan kategori kurang.

\section{Pertolongan pertama dalam keluarga pada penanganan balita diare dalam kategori baik}

Berdasarkan hasil penelitian didapatkan dari 32 anggota keluarga sebagian besar keluarga $\quad 62.5 \% \quad$ (20 keluarga) memiliki pertolongan pertama baik dalam penanganan balita diare. Menurut Bahren (2014:35) saat balita mengalami diare dapat dilakukan beberapa pertolongan di rumah, yaitu memberikan cairan lebih banyak dari biasanya, memberikan nutrisi yang cukup dan menentukan kapan perlu berobat ke sarana kesehatan. Menurut pendapat peneliti, keluarga yang mempunyai pertolongan pertama baik dikarenakan pada saat balita diare, keluarga sudah memberikan cairan lebih banyak dari biasanya yang dapat mengurangi terjadinya dehidrasi pada balita diare. Hal ini dapat ditinjau berdasarkan indikator memberikan cairan lebih banyak dari biasanya yang menyatakan bahwa seseorang yang mengalami diare membutuhkan cairan lebih banyak dari biasanya karena cairan tubuh yang hilang lewat tinja dan terkadang disertai muntah.

Hasil penelitian didapatkan seluruh anggota keluarga 100\% (32 keluarga) memberikan cairan lebih banyak dari biasanya saat balita mengalami diare. Hal ini dapat dipengaruhi juga karena beberapa faktor, seperti faktor pengalaman keluarga dalam menangani balita diare yaitu memberikan cairan lebih banyak dari biasanya sebanyak $31.3 \%$ (10 keluarga). Sehingga dengan pengalaman yang diperoleh, keluarga lebih siap untuk melakukan pertolongan pertama pada saat ada anggota keluarga yang menderita diare

Selain memberikan cairan lebih banyak dari biasanya, faktor lain pertolongan pertama dengan kategori baik yaitu segera membawa balita berobat ke fasilitas kesehatan saat diare memberat. Seseorang yang sedang sakit pada umumnya memiliki perilaku yang biasanya disebut perilaku sakit, perilaku ini mencakup cara seseorang memantau tubuhnya, mendefinisikan dan menginterpretasikan gejala yang dialaminya, melakukan upaya penyembuhan, dan menggunakan sistem pelayanan kesehatan. Menurut Friedman dalam Setiadi (2008:12-13) membagi 5 tugas keluarga dalam bidang kesehatan yang harus dilakukan, yaitu: mengenal masalah kesehatan setiap anggotanya, mengambil keputusan untuk melakukan tindakan yang tepat bagi 
keluarga, memberikan perawatan anggotanya yang sakit atau yang tidak dapat membantu dirinya sendiri karena cacat atau usianya yang terlalu muda, mempertahankan suasana di rumah yang menguntungkan kesehatan dan perkembangan kepribadian anggota keluarga dan mempertahankan hubungan timbal balik antara keluarga dan lembaga kesehatan (pemanfaatan fasilitas kesehatan yang ada). Peneliti berpendapat bahwa jika ada anggota keluarga yang sakit, keluarga mempunyai kewajiban untuk membawa anggota keluarganya yang sakit ke fasilitas kesehatan.

Hal ini dibuktikan dengan hampir seluruh keluarga 97\% (30 keluarga) membawa balita berobat ke fasilitas kesehatan saat diare memberat. Menurut Bahren (2014:34) balita yang menderita diare harus segera periksa ke fasilitas kesehatan apabila terdapat lendir atau darah dalam tinja, karena hal ini menunjukkan bahwa balita sedang terinfeksi disentri. Balita mengalami diare lebih sering, muntah berulang, sangat haus, makan/minum sedikit, timbul demam, tinja berdarah, tidak membaik dalam 3 hari. Sehingga keluarga mempunyai kesadaran penuh akan pentingnya membawa balita diare periksa ke fasilitas kesehatan.

\section{Pertolongan pertama dalam keluarga pada penanganan balita diare dalam kategori cukup.}

Berdasarkan hasil penelitian didapatkan dari 32 anggota keluarga, sebagian kecil keluarga $28.1 \%$ (9 keluarga) melakukan pertolongan pertama balita diare dengan kategori cukup. Hal ini disebabkan oleh sebagian kecil 34\% (11 keluarga) tidak memberikan cairan meskipun diare sudah berhenti.

Menurut Wong (2008) setelah rehidrasi, cairan seperti oralit atau air matang dapat digunakan dalam terapi rumatan pada penderita diare agar tidak terjadi dehidrasi berulang atau gangguan keseimbangan elektrolit. Bahaya dehidrasi ini tidak dikhawatirkan oleh sebagian masyarakat karena adanya stigma bahwa diare sering dikatakan tidak apa-apa, karena diare berarti "ngentengin badan" dan dengan demikian balita akan bertambah pintar (Noorkasiani, 2009:48). Keyakinan masyarakat yang didasari oleh kultur sering menentukan definisi tentang kesehatan dan penyakit bagi orang yang mempunyai sistem keyakinan tradisional. Kepercayaan merupakan keyakinan bahwa suatu fenomena atau objek benar atau nyata, biasanya kepercayaan diterima tanpa bukti bahwa kepercayaan itu memang benar (Widyastuti, 2005).

Peneliti berpendapat bahwa terapi rumatan untuk balita diare sangat penting untuk mencegah dehidrasi berulang karena apabila balita kehilangan banyak cairan dapat 
menyebabkan kematian, tetapi masyarakat beranggapan bahwa setelah diare balita berhenti cairan tidak perlu diberikan kembali. Hal ini dikarenakan adanya kepercayaan masyarakat bahwa diare dapat ngentengin badan dan membuat anak pintar. Dibuktikan dari hasil tabulasi silang antara pertolongan pertama dan kepercayaan sebagian kecil $25 \%$ (8 keluarga) mempunyai anggapan bahwa diare berarti "ngentengin badan" dan membuat anak pintar.

\section{Pertolongan pertama dalam keluarga pada} penanganan balita diare dalam kategori

\section{kurang.}

Berdasarkan hasil penelitian didapatkan dari 32 anggota keluarga, sangat sedikit keluarga $9.4 \%$ (3 keluarga) melakukan pertolongan pertama balita diare dengan kategori kurang. Hal ini disebabkan sebagian besar keluarga 78\% (25 keluarga) masih memberikan obat antidiare pada saat balita mengalami diare.

Komplikasi dari penyakit diare adalah dehidrasi, dehidrasi dapat dicegah dengan memberikan cairan yang tepat dalam jumlah yang memadai. Cairan yang dimaksud yaitu lautan garam oralit, apabila tidak ada oralit di rumah, dapat digunakan larutan gula garam yang hampir sama efektifnya dengan oralit dengan takaran 1 sendok makan $( \pm 20 \mathrm{~g})$ dan garam dapur 1 sendok teh $(3,5 \mathrm{~g})$ dilarutkan dalam 1 liter air matang. Selain itu, bermacam- macam cairan rumah tangga juga dapat dikonsumsi untuk mencegah dehidrasi seperti air tajin, kuah sayur, atau air matang, (Depkes RI, 2011:14).Menurut Bahren (2014:34) berbagai macam obat dan kombinasi obat dijual untuk pengobatan diare akut yaitu obat antidiare meliputi antimotilitas, adsorben dan biakan bakteri hidup. Namun, tidak satupun obat-obatan ini terbukti mempunyai efek yang nyata untuk diare akut. Bahkan, obat-obat ini tidak boleh diberikan pada anak yang berusia dibawah 5 tahun. Selain obat antidiare, antibiotika juga tidak boleh digunakan secara rutin untuk diare akut. Antibiotik hanya bermanfaat bagi penderita disentri, kolera, atau diare persisten. Penggunaan obat antidiare, anti muntah, dan antibiotik sering memperlambat pemberian oralit (cairan) dan bahkan dapat menghambat (menunda) pertolongan ke sarana kesehatan.

Dari hasil wawancara langsung kepada sebagian kecil keluarga, keluarga masih memberikan obat antidiare pada saat balita mengalami diare karena obat antidiare yang dijual bebas di masyarakat sehingga keluarga mudah untuk membelinya saat balita mengalami diare, dan beranggapan bahwa balita yang mengalami diare diberikan obat antidiare agar diarenya berhenti

Selain itu, pertolongan pertama keluarga yang kurang juga dipengaruhi oleh pemberian susu formula bebas laktosa saat balita 
mengalami diare. Sebagian keluarga 53\% (17 keluarga) mengganti susu formula balita dengan susu formula bebas laktosa saat balita mengalami diare. Menurut Wong (2008) bayi dan anak diare yang mendapatkan terapi hidrasi yang baik dapat terus minum susu formula non-ASI dengan pengenceran seperti semula. Pemakaian susu formula bebas laktosa hanya jika susu yang biasa diberikan tidak dapat ditoleransi oleh bayi atau anak diare. Menurut pendapat peneliti, seharusnya balita yang mengalami diare tidak perlu langsung mengganti susu formula dengan susu formula bebas laktosa dikarenakan tidak semua balita diare disebabkan oleh intoleransi susu (malabsorbsi karbohidrat), penyebab utama penyakit diare adalah infeksi bakteri atau virus yang jalur masuknya melalui feses manusia atau binatang, makanan, air, dan kontak dengan manusia.

\section{Kesimpulan Dan Saran}

Berdasarkan hasil penelitian gambaran pertolongan pertama pada keluarga dalam penanganan balita diare di Poli MTBS UPTD Puskesmas se-Kota Blitar pada 17 April - 06 Mei 2018 dengan jumlah responden 32 keluarga didapatkan hasil sebagian besar keluarga $62.5 \%$ (20 keluarga) melakukan pertolongan pertama balita diare dengan kategori baik, sebagian kecil keluarga $28.1 \%$ (9 keluarga) melakukan pertolongan pertama balita diare dengan kategori cukup baik, dan sangat sedikit keluarga 9.4\% (3 keluarga) melakukan pertolongan pertama balita diare dengan kategori kurang. Pertolongan pertama baik dipengaruhi oleh seluruh anggota keluarga memberikan cairan lebih banyak dari biasanya saat balita mengalami diare dan segera membawa ke fasilitas kesehatan.

Sesuai dengan kesimpulan yang telah dikemukakan, peneliti ingin memberikan beberapa saran sebagai berikut:

1) Bagi Instansi Pendidikan

Hasil penelitian ini dapat digunakan sebagai referensi dan bahan tambahan untuk mengembangkan informasi dalam pertolongan pertama pada penanganan balita diare untuk mencegah terjadinya dehidrasi.

2) Bagi Instansi Kesehatan

Dari hasil penelitian ini diharapkan dapat digunakan sebagai bahan penyusunan kebijakan program penyakit menular dalam hal pertolongan pertama diare di Dinas Kesehatan Kota Blitar.

\section{3) Bagi Tempat Penelitian}

Dari hasil penelitian ini diharapkan dapat digunakan sebagai bahan penyusunan kegiatan dalam hal pertolongan pertama diare di UPTD Puskesmas se-Kota Blitar, terutama pendidikan kesehatan tentang langkah-langkah pertolongan pertama diare di rumah sebelum dibawa ke fasilitas kesehatan. 
4) Bagi Peneliti Lain

Dari hasil penelitian ini diharapkan peneliti selanjutnya dapat dikembangkan lagi dengan menggali faktor-faktor yang mempengaruhi pertolongan pertama dalam keluarga pada penanganan balita diare.

\section{Referensi}

Afrilianto. (2012). Orang Tua Cermat, Anak Sehat. Jakarta: Gagas Media.

Arikunto, S. (2010). Prosedur Penelitian Suatu Pendekatan Praktik. Jakarta: Rineka Cipta.

Bahren, D. (2014). Majalah Kesehatan Muslim: Menjaga Kesehatan di Musim

Hujan. Jakarta: Pustaka Muslim.

Departemen Kesehatan RI..(2011). Buku Saku

Petugas Kesehatan Lima Langkah

Tuntaskan Diare. Jakarta:

Dinas Kesehatan Jawa Timur. (2015). Profil

Kesehatan Provinsi Jawa Timur

Surabaya: Dinkes Jawa Timur.

Dinas Kesehatan Kota Blitar. (2015). Profil

Kesehatan Kota Blitar

Hidayat, A. A. A. (2008). Pengantar Ilmu

Keperawatan Anak 1. Jakarta: Salemba Medika.

Hidayat, A. A. A. (2008). Pengantar Ilmu

Keperawatan Anak 2. Jakarta: Salemba Medika.

Kementerian Kesehatan RI. (2011). Situasi

Diare di Indonesia. Jakarta: Kemkes RI.
Lalani, A. \& Schneeweiss, S. (2011). Kegawatdaruratan Pediatri. Jakarta: EGC.

Noorkasiani. (2009). Sosiologi Keperawatan. Jakarta: EGC.

Nursalam. (2011). Konsep dan Penerapan Metode Penelitian Ilmu Keperawatan. Jakarta: Salemba Medika.

Nursalam. (2013). Metodologi Penelitian Ilmu Keperawatan: Pendekatan Praktik Edisi 3. Jakarta: Salemba Medika.

Peraturan Menteri Kesehatan Republik Indonesia Nomor 44 Tahun (2016) Tentang Pedoman Manajemen Puskesmas.

Soeroso, A. (2008). Sosiologi 1. Bogor: Yudhistira.

Setiadi. (2008). Konsep dan Proses Keperawatan Keluarga . Yogyakarta: Graha Ilmu.

Sutomo, B. \& Anggraini, D. Y. (2010). Menu Sehat Alami Untuk Batita \& Balita. Jakarta: Demedia.

Sutomo, B. \& Anggraini, D. Y.. (2008). Mengatasi Diare \& Keracunan pada Balita. Jakarta: Kawan Pustaka.

Wiyono, J. (2013). Tumbuh Kembang Keluarga. Malang: Universitas Negeri Malang.

Widyastuti, P. (2005). Penyakit Bawaan Makanan: Fokus Pendidikan Kesehatan. Jakarta: EGC. 
Setijaningsih, Triana Dan Hawari, Rahmawati. Gambaran Pertolongan Pertama Dalam Keluarga Pada Penanganan Balita Diare Di Poli MTBS UPTD Puskesmas Se-Kota Blitar. Journal of Borneo Holistic Health, Vol.3, No. 2 Desember 2020 hal 129-139

Wong, D. L. (2008). Buku Ajar Keperawatan Pediatrik Wong, Ed. 6, Vol.2. Alih Bahasa

World Health Organization. (2008). Indikator Perbaikan Kesehatan Lingkungan Anak.

Alih Bahasa Aprianingsih. Jakarta: EGC 